\title{
Liver morphology in acute viral hepatitis related to the hepatitis $\mathrm{B}$ antigen ${ }^{1}$
}

\author{
S. IWARSON, P. LUNDIN, AND S. HERMODSSON \\ From the Departments of Infectious Diseases, Pathology I, and Clinical Virology, \\ University of Göteborg, Göteborg, Sweden
}

SYNOPSIS The liver histology in infectious hepatitis or hepatitis A (HA) and serum hepatitis or hepatitis B (HB) is generally described as identical. However, the clinical separation of the two types? has been a problem. Today a serological reaction based on the well documented association ov between hepatitis antigen and HB is of great assistance in the differential diagnosis. The present $\vec{\circ}$ study of 165 hepatitis cases separated into hepatitis Aand B by this test methodindicates quantitative o differences in the liver histology of the two types. Thus HB was associated with more prominent parenchymal cell damage and Kupffer cell reaction, while intrahepatic cholestasis was found in $\subseteq$ a significantly higher frequency in cases presumed to represent HA.

The presence of intrahepatic cholestasis was associated with higher levels of serum bilirubin but otherwise no correlation was found between liver morphology and biochemical liver tests.

The patients included a group of young intravenous amphetamine addicts with HB. No differences of importance were found histologically in addicts and other patients with hepatitis B.

In the late thirties needle aspiration liver biopsy was developed into a clinically applicable technique by Roholm and Jversen (1939) and became a useful tool for the study of liver morphology in viral hepatitis. Extensive information has been obtained after that by examination of needle biopsy specimens from non-fatal cases of viral hepatitis (Axenfeld and Brass, 1942; Dible, McMichael, and Sherlock, 1943; Weinbren, 1952). The two main types, ie, infectious hepatitis A (HA) and serum hepatitis B (HB), have been described as histologically identical (Dible $e t$ al, 1943; Bianchi, 1967). However, the lack of a test offering a mean to distinguish between the two types has always been a problem since it is often impossible co differentiate between them on clinical or epidemiological grounds. Today the documented association between the hepatitis-associated antigen (HAA) and hepatitis B (Prince, 1968; Krugman and Giles, 1970) has opened a new possibility of separating sporadically occurring HA from HB and has inspired the present comparative study of liver morphology in the two main types of viral hepatitis, including also a study of the correlation between histological and biochemical findings.

('This study was supported by the Swedish Medical Research Council project no. B71 - 21X - 3169-01).

Received for publication 27 July 1972.

\section{Material and Methods}

PATIENTS

Liver biopsy was performed routinely in hepatitis patients admitted to the Clinic for Infectious Diseases, Göteborg, Sweden, during the period February 1969 until October 1971. The present study includes patients with a clinical and histopathological diagnosis of viral hepatitis, 15-44 years of age, and with a maximal level of serum bilirubin above $2.5 \mathrm{mg} / 100 \mathrm{ml}$. Only patients in whom liver biopsy was performed during the period of elevated serum 0 bilirubin ( $\geqslant 1.5 \mathrm{mg} / 100 \mathrm{ml})$ and who were tested for HBAg within 10 days after the onset of jaundice의 (or observation of dark urine), were included in the study.

In all 165 hepatitis patients fulfilled the above criteria and 114 (including 55 drug addicts) had ( demonstrable HBAg in acute phase serum, while 51 N patients had no detectable $\mathrm{HBAg}$. The mean age of ${ }_{\mathrm{E}}^{\mathrm{N}}$ the HBAg-negative group was 28 years, while the mean age of the $\mathrm{HBAg}$-positive group was 22 years in the drug addicts and 27 years in the HBAg-positive patients of other categories. The addicts had usedof drugs intravenously (mostly amphetamines) but none of them had been icteric before the actualo attack of serum hepatitis. The non-addicted patients 
with HBAg in serum were mainly hospital personnel but included also sporadic cases without known exposure to hepatitis. The patients without detectable HBAg included no drug addict or hospital worker and about half of this group had had intrafamilial hepatitis contacts or had visited endemic hepatitis areas within two months of the onset of jaundice.

The patients were treated in the same fashion. They were admitted to hospital during the period of overt jaundice and after that followed up regularly as outpatients as described in a previous report (Iwarson and Hermodsson, 1971).

\section{LIVER BIOPSY}

In 72 patients biopsy was performed before serum bilirubin had reached the maximal level (here referred to as the 'early icteric phase of illness'), while in the remaining 93 patients liver biopsy was performed during the period of declining serum bilirubin (referred to as the 'late icteric phase'). The mean duration from onset of jaundice till performance of liver biopsy was eight days for the HBAgnegative cases and 11 days for the HBAg-positive cases of the early icteric phase, while the mean duration was 13 and 17 days respectively for the patients being biopsied during the late icteric phase.

Needle biopsy was performed by a transthoracic route according to a modified Menghini technique (Lundvall and Iwarson, 1970). Only a few patients had to be excluded from liver biopsy because of coagulation abnormalities but 15 addicts refused biopsy. No serious complications occurred.

\section{LABORATORY METHODS}

Serum specimens were obtained weekly during the hospital stay and at about two weeks' interval during the follow-up period, which was continued until the liver function tests had become normal.

Hepatitis B antigen was demonstrated in serum by a micromodification of the Ouchterlony doublediffusion method as described previously (Iwarson and Hermodsson, 1971). Sera found to be HBAgnegative with this method were also tested by an immunoelectroosmophoresis technique as described by Hansson, Kindmark, and Johnsson (1970).

The biochemical liver tests-total serum bilirubin, serum alkaline phosphatase, and serum glutamic pyruvic transaminase (SGPT) - were determined as also described in a previous report (Iwarson and Hermodsson, 1971). The study of a possible relationship between serum levels of alkaline phosphatase and intrahepatic cholestasis histologically included only patients 20 years or older since younger persons have different normal limits of serum alkaline phosphatases.

\section{HISTOPATHOLOGICAL METHODS AND}

DEFINITIONS

All slides were examined by the pathologist of the group without knowledge of clinical, biochemical, or serological data. The biopsy specimens were fixed in $10 \%$ formaldehyde, embedded in paraffin, and sectioned. The sections were stained with haematoxylin-eosin and haematoxylin-van Gieson. Iron was demonstrated with the prussian blue method as modified by Hutchison (1953). The reticulin fibres were revealed by silver impregnation according to a modification (Gurr, 1962) of the Laidlaw method.

The histological description of the morphologica! features was according to the principles given by an international group in a recent review (Bianchi, De Groote, Desmet, Gedigh, Korb, Popper, Poulsen, Scheuer, Schmid, Thaler, and Wepler, 1971). The following lobular lesions were studied: parenchymal cell damage, proliferation of sinusoid lining (Kupffer) cells, cholestasis in the form of 'bile plugs' or 'bile thrombi', accumulation of ceroid and iron pigments in sinusoid lining cells, and histiocytes. The various changes were graded according to the following schedule:

\section{Parenchymal cell damage}

(+) Slight to moderate hydropic degeneration without acidophil degeneration.

$+\quad$ Pronounced hydropic degeneration, some balloon cells, and a few acidophil cells or hyaline bodies (Councilman bodies).

++ Apparent ballooning of the cytoplasm and several hyaline cells or hyaline bodies.

+++ General ballooning of the cytoplasm with several acidophil cells and hyaline bodies.

\section{Intrahepatic cholestasis}

- $\quad$ No visible bile thrombi.

$+\quad$ A few small thrombi in the centre of some lobuli.

++ Multiple small thrombi in the centre of most lobuli.

The bile accumulation in the parenchymal liver cells, which was fairly well correlated to the number of bile thrombi, was not graded.

The proliferation of Kupffer cells was graded slight $(+)$, moderate + , or pronounced ++ , while the accumulation of ceroid and iron pigments in the Kupffer cells were classified as,-+ or ++ , according to a definition given previously for iron (Lundvall, Weinfeld, and Lundin, 1969).

In the portal areas accumulation of inflammatory cells, fibroblastic activity, and bile duct proliferation 
were studied. The portal accumulation of inflammatory cells was graded as slight $(+)$, moderate + , or pronounced ++ .

\section{Results}

\section{LIVER MORPHOLOGY}

The morphological lesions in the 165 hepatitis patients are summarized in Table I. In general, no differences were found between the early and late phases of jaundice, but ceroid pigmentation of phagocytes was more common during the late icteric phase $(\mathrm{P}<0.05)$. This pigmentation was also noted in a higher frequency within non-addicted HBAgpositive patients $(P<0.05)$. Otherwise no significant differences were found between drug addicts and others within the HBAg-positive group. Neither were any further significant differences found in the lesions of the early and late icteric phases.

The comparison of the liver histology in patients with and without demonstrable HBAg was made without differentiation of the material into early and late icteric phases, and certain quantitative histological differences appeared (Fig. 1). Thus pronounced parenchymal cell damage $(++$ or +++$)$ as well as proliferation of Kupffer cells $(++)$ was found at a significantly higher frequency within the HBAgpositive group ( $\mathrm{P}<0.01$ and $\mathrm{P}<0.05$ respectively). On the other hand the presence of intrahepatic bile stasis $(+$ or ++$)$ in the form of bile thrombi was

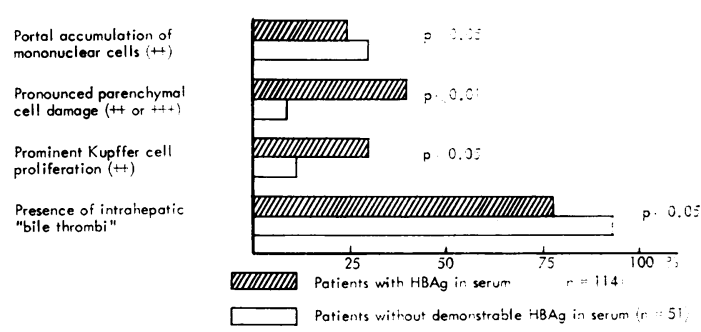

Fig. 1. Comparison of prominent morphological lesions in 165 hepatitis patients. The grading $+\div$ and $+\div$ is defined in the text

more common within the HBAg-1,egative groupi $(P<0.05)$. Only three HBAg-negative patients $(6 \%)$ were completely without visible intrahepatic bile thrombi, while this was the case in 26 of the HBAg-positive patients $(23 \%)$.

The portal accumulation of inflammatory cells showed no significant differences in the HBAgO positive and HBAg-negative groups of patients? Obvious bile duct proliferation was found in six patients (two with $\mathrm{HBAg}$ ) and histological signs of fibroblastic activity with proliferation and increasee in the number of fibroblasts was also noted in gix patients (five with $\mathrm{HBAg}$ ). In no patient was apparent tendency to septal formation noted.

The morphological lesions showed no

\begin{tabular}{|c|c|c|c|c|c|c|c|}
\hline \multirow[b]{3}{*}{ Morphological Lesions } & & \multicolumn{3}{|c|}{ Early Icteric Phase } & \multicolumn{3}{|c|}{ Late Icteric Phase } \\
\hline & & \multicolumn{2}{|c|}{ HBAg-positive Patients (\%) } & \multirow{2}{*}{$\begin{array}{l}\text { HBAg-negative } \\
\text { Patients }(\%) \\
n=21\end{array}$} & \multicolumn{2}{|c|}{ Au-positive Patients (\%) } & \multirow{2}{*}{$\begin{array}{l}\text { HBAg-negati } \\
\text { Patients }(\%) \\
n=30\end{array}$} \\
\hline & & $\begin{array}{l}\text { Addicts } \\
n=24\end{array}$ & $\begin{array}{l}\text { Others } \\
n=27\end{array}$ & & $\begin{array}{l}\text { Addicts } \\
n=31\end{array}$ & $\begin{array}{l}\text { Others } \\
n=32\end{array}$ & \\
\hline Parenchymal cell damage & $\begin{array}{l}(+) \\
+ \\
++ \\
++t\end{array}$ & $\begin{array}{r}0 \\
67 \\
33 \\
0\end{array}$ & $\begin{array}{r}0 \\
56 \\
41 \\
4\end{array}$ & $\begin{array}{r}14 \\
71 \\
14 \\
0\end{array}$ & $\begin{array}{r}13 \\
61 \\
26 \\
0\end{array}$ & $\begin{array}{r}9 \\
47 \\
37 \\
6\end{array}$ & $\begin{array}{r}13 \\
83 \\
3 \\
0\end{array}$ \\
\hline Proliferation of Kupffer cells & $\begin{array}{l}(+) \\
+ \\
++\end{array}$ & $\begin{array}{r}0 \\
58 \\
42\end{array}$ & $\begin{array}{r}0 \\
70 \\
30\end{array}$ & $\begin{array}{r}0 \\
81 \\
19\end{array}$ & $\begin{array}{r}3 \\
68 \\
29\end{array}$ & $\begin{array}{r}0 \\
78 \\
22\end{array}$ & $\begin{array}{r}3 \\
90 \\
7\end{array}$ \\
\hline Intrahepatic cholestasis (bile thrombi) & $\begin{array}{l}- \\
+ \\
+\end{array}$ & $\begin{array}{r}25 \\
67 \\
8\end{array}$ & $\begin{array}{l}26 \\
44 \\
30\end{array}$ & $\begin{array}{r}5 \\
43 \\
52\end{array}$ & $\begin{array}{r}23 \\
70 \\
7\end{array}$ & $\begin{array}{r}19 \\
75 \\
6\end{array}$ & $\begin{array}{r}7 \\
63 \\
30\end{array}$ \\
\hline $\begin{array}{l}\text { Accumulation of iron pigment in } \\
\text { phagocytes }\end{array}$ & $\begin{array}{l}- \\
+ \\
+\end{array}$ & $\begin{array}{l}67 \\
17 \\
17\end{array}$ & $\begin{array}{l}55 \\
30 \\
15\end{array}$ & $\begin{array}{l}38 \\
24 \\
38\end{array}$ & $\begin{array}{r}58 \\
32 \\
9\end{array}$ & $\begin{array}{l}69 \\
16 \\
15\end{array}$ & $\begin{array}{l}50 \\
37 \\
13\end{array}$ \\
\hline $\begin{array}{l}\text { Accumulation of ceroid pigment in } \\
\text { phagocytes }\end{array}$ & $\begin{array}{l}- \\
+ \\
+\end{array}$ & $\begin{array}{r}83 \\
13 \\
4\end{array}$ & $\begin{array}{r}48 \\
48 \\
4\end{array}$ & $\begin{array}{r}77 \\
24 \\
0\end{array}$ & $\begin{array}{l}54 \\
35 \\
10\end{array}$ & $\begin{array}{r}19 \\
78 \\
3\end{array}$ & $\begin{array}{r}57 \\
37 \\
7\end{array}$ \\
\hline $\begin{array}{l}\text { Portal accumulatlon of inflammatory } \\
\text { cells }\end{array}$ & $\begin{array}{l}(+) \\
+ \\
++\end{array}$ & $\begin{array}{c}0 \\
69 \\
31\end{array}$ & $\begin{array}{r}4 \\
63 \\
33\end{array}$ & $\begin{array}{r}0 \\
62 \\
38\end{array}$ & $\begin{array}{r}3 \\
68 \\
29\end{array}$ & $\begin{array}{r}0 \\
84 \\
16\end{array}$ & $\begin{array}{r}3 \\
73 \\
23\end{array}$ \\
\hline
\end{tabular}


differences except for iron pigmentation of phagocytes, which was more common in males $(\mathrm{P}<0.01)$. This might be explained by a larger hepatic iron store in men (Weinfeld, Lundin, and Lundvall, 1968).

CORRELATION BETWEEN HISTOLOGICAL AND BIOCHEMICAL FINDINGS

The maximal levels of serum bilirubin and SGPT were compared in patients with parenchymal cell damage classified as $(+)$ or + , and in patients with more severe parenchymal cell damage $(++$ or $+++)$. However, no significant differences were found, either within the HBAg-positive or within the HBAg-negative group of patients $(P<0.05)$.

A study of the relationship between intrahepatic cholestasis and the maximal levels of serum bilirubin, serum alkaline phosphatases and SGPT respectively, was also performed within the HBAg-positive and HBAg-negative groups of patients. Higher levels of serum bilirubin were noted in cases with intrahepatic cholestasis $(+$ or ++$)$ as compared with patients with no signs of intrahepatic cholestasis (Fig. 2). The difference was significant both for the $\mathrm{HBAg}$-positive group $(P<0.01)$ and for the HBAg-negative group of patients $(P<0.05)$. No such differences were found for the maxmial levels of serum alkaline phosphatases or SGPT.

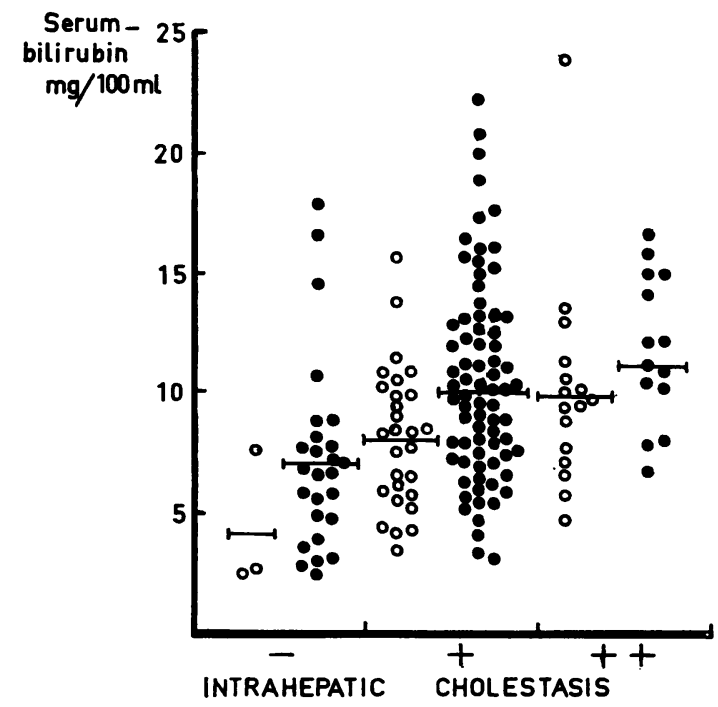

Fig. 2 Correlation between maximal levels of serum bilirubin and intrahepatic cholestasis, classified as

- (lacking), + (moderate), and ++ (pronounced).

HBAg-positive patients $(n=114)$

HBAg-negative patients $(n=51)$

- Mean value.

\section{Discussion}

Earlier observations of an identical liver histology in infectious hepatitis or hepatitis A (HA) and serum hepatitis or hepatitis B (HB) were largely confirmed. The classic histological picture with diffuse necrosis and inflammation of the parenchyma with or without coexistent intrahepatic cholestasis dominated in both types, and it was impossible to differentiate between them on histological grounds. However, apparent quantitative differences in the histological lesions were noted. Patients with hepatitis-B antigen in the serum, who are considered as cases of HB, showed more pronounced parenchymal cell damage and more prominent Kupffer cell reaction as compared with HBAg-negative patients, who are considered as cases of HA. On the other hand the latter group had a higher incidence of intrahepatic cholestasis in the form of 'bile thrombi'. The finding of more severe parenchymal cell damage as well as Kupffer cell reactions in sporadic serum hepatitis, as compared with HAA-negative hepatitis, is in accordance with the more severe clinical and biochemical features found in hepatitis associated with HBAg (Iwarson and Hermodsson, 1971).

Mallory (1947) described intrahepatic cholestasis as a very common histological feature in viral hepatitis, and in the large Delhiepidemic of infectious hepatitis Gupta and Smetana (1957) found prominent features of intrahepatic cholestasis in $58 \%$ of a series including 78 biopsy cases. Dubin, Sullivan, LeGolvan, and Murphy (1960) tried to separate HA from $\mathrm{HB}$ and they noted a significantly higher frequency of intrahepatic cholestasis in a minor epidemic of HA in Texas, but suggested some unusual strain of the hepatitis A virus as responsible for this finding, since no corresponding results had been reported in earlier studies of sporadically occurring HA (Dible et al, 1943). In the present study the total frequency of intrahepatic cholestasis in the material corresponds well with the frequency reported by Mallory and when a differentiation into HA and HB is made a significantly higher frequency of intrahepatic cholestasis is found in HA. This is in accordance with the reports from the Delhi and Texas epidemics, indicating that in hepatitis material, where $\mathrm{HB}$ has been excluded epidemiologically, or by a serological test, a higher frequency of intrahepatic cholestasis is found.

Histological features of intrahepatic cholestasis were regularly seen together with hepatocellular and mesenchymal alterations, and the cases with intrahepatic cholestasis as a prominent feature differed only quantitatively from the classic histological type of hepatitis. This has also been pointed out by others (Gupta and Smetana, 1957; Dubin et al, 1960). A 
pure cholestatic variant of viral hepatitis with a prolonged and atypical clinical course has been described (Watson and Hoffbauer, 1946; Shaldon and Sherlock, 1957). This type seems to be rare and is mostly found in older age groups (Gall and Braunstein, 1955). No such case was observed in the present material.

The mechanism of intrahepatic cholestasis in viral hepatitis is not clear, but it is probably secondary to dysfunction of the bile secretory apparatus of the hepatocyte, which might cause a change in the composition of secreted bile, followed by precipitates in the bile canaliculi (Mosley and Galambos, 1965).

The amphetamine addicts included in the present study showed histological features of the same kind and of about the same incidence and distribution as the other patients within the HBAg-positive group. This is in accordance with earlier observations (Iwarson and Hermodsson, 1971; Iwarson and Holmgren, 1972) in favour of a similar nature of acute hepatitis B in young amphetamine addicts and other patients.

An important factor in a comparative morphological study such as the present one is the time for liver biopsy in relation to duration of illness since the histological features change during the course of the disease (Dubin, 1959; Bianchi, 1967; Bianchi et al, 1971). For that reason the present study includes only patients in whom liver biopsy was obtained during the icteric period or what Bianchi has called 'the fully developed stage of the disease' (Bianchi, 1967). As a rule liver biopsy was performed a few days closer to the onset of jaundice in the HBAgnegative patients, but it is unlikely that this is of any importance since only slight histological differences were found between the early and late phases of the icteric period.

Intrahepatic cholestasis histologically was associated with higher maximal levels of serum bilirubin. Similar findings have been reported by others (Weinbren, 1952; Gall and Braunstein, 1955). However, no correlation was found between the parenchymal cell damage and the maximal levels of serum bilirubin or SGPT. This is not an unusual finding and it is well known that severe liver cell damage may be found in patients with clinically mild and anicteric hepatitis, while a severe clinical illness is not necessarily accompanied by extensive necrosis on liver biopsy (Bianchi et al, 1971). It has been suggested that sampling error might play a role in this often noted discrepancy between liver morphology and biochemical liver tests (Mosley and Galambos, 1965), but even if the sampling error might be a problem in needle biopsy studies of liver histology, the lesions in viral hepatitis tend to be diffuse throughout the liver and the histological appearance quite uniform in any one patient (Dible et al, 1943). A more probable 0 explanation for the difference may be that the out $-\frac{0}{7}$ come of the usual liver function tests is dependent $\underline{\text { o }}$ not only on the extent and severity of the histological parenchymal necrosis, but also on the functional@ capacity of morphologically intact hepatocytes on? light microscopy. Cystic dilatation and fragmenta-흠. tion of the endoplasmatic reticulum in surviving liver $\frac{\bar{\sigma}}{\sigma}$ cells are detectable by the electron microscope, $\stackrel{\mathbb{Q}}{\varrho}$ suggesting impairment of several specific functions (Schaffner, 1966).

\section{References}

Axenfeld, H., and Brass, K. (1942). Klinische und bioptische Unter suchungen über den sogenannten Icterus catarrhalis. Frankfurt. 0 Z. Path., 57, 147-236.

Bianchi, L. (1967). Histologisches Bild und morphologische Differential diagnose der Hepatitis. In Punktat-Morphologie und Differenti- $\overrightarrow{-}$ aldiagnose der Hepatitis, edited by Leonardo Bianchi, pp. $32-$ 45. Huber, Berne and Stuttgart.

Bianchi, L., de Groote, J., Desmet, V. J., Gedigk, P., Korb, G.Љ Popper, H., Poulsen, H., Scheuer, P. J., Schmid, M., Thalero H., and Wepler, W. (1971). Morphological criteria in vira hepatitis; review by an international group. Lancet, 1, 333-337.-

Dible, J. H., McMichael, J., and Sherlock, S. P. V. (1943). Pathology○ of acute hepatitis; aspiration biopsy studies of epidemic $\Omega$ arsenotherapy and serum jaundice. Lancet, 2, 402-408.

Dubin, I. N. (1959). Intrahepatic bile stasis in acute nonfatal vira? hepatitis; its incidence, pathogenesis and correlation with

jaundice. Gastroenterology, 36, 645-660.
Dubin, I. N., Sullivan, B. H., Jr., LeGolvan, P. C., and Murphy $\vec{\vartheta}$ L. C. (1960). The cholestatic form of viral hepatitis-QxN periences with viral hepatitis at Brooke Army Hospital duㅜㅜㅇ the years 1951 to 1953 . Amer. J. Med., 29, 55-72.

Gall, E. A., and Braunstein, H. (1955). Hepatitis with manifestat simulating bile duct obstruction (so-called 'cholangiofitie hepatitis'). Amer. J. clin. Path., 25, 1113-1127.

Gupta, D. N., and Smetana, H. F. (1957). The histopathology of vira hepatitis as seen in the Delhi epidemic 1955-1956. Indian $J \mathbb{D}$ med. Res., 45, Suppl.,101-113.

Gurr, E. (1962). Staining Animal Tissues, p. 267. Hill, London.

Hansson, B. G., Kindmark, C. O., and Johnsson, T. (1970). Comparisor between the immunoelectroosmophoresis and the Ouchterlon precipitation technique in detecting Australia antigen in case? of hepatitis. Vox Sang. (Basel), 19, 225-227.

Hutchison, H. E. (1953). The significance of stainable iron in sternat marrow sections. Its application in the control of iron therapy) Blood, 8, 236-248.

Iwarson, S., and Hermodsson, S. (1971). Hepatitis-associated antige (HAA) in acute viral hepatitis; serological and clinical studies. Scand. J. infect. Dis., 3, 93-101.

Iwarson, S., and Holmgren, J. (1972). Patterns of immunoglobulins iจ acute viral hepatitis: relation to the hepatitis-associate $\Phi$ antigen. J. infect. Dis., 125, 178-182.

Krugman, S., and Giles, J. P. (1970). Viral hepatitis: new light o욤 an old disease. J. Amer. med. Ass., 212, 1019-1029.

Lundvall, O., and Iwarson, S. (1970). Experiences with two simpto aspiration liver biopsy techniques. Acta med. scand., 18푸. 225-228.

Lundvall, O., Weinfeld, A., and Lundin, P. (1969). Iron stores iळ్ alcohol abusers. I. Liver iron. Acta med. scand., 185, 259-26

Mallory, T. B. (1947). The pathology of epidemic hepatitis. J. Ame med. Ass., 134, 655-662.

Mosley, J. W., and Galambos, J. T. (1969). Pathology of viral hepatitis. In Diseases of the Liver, edited by Leon Schiff, 3rd ed., pe् 436-446. Lippincott, Philadelphia, Toronto.

Prince, A. M. (1968). An antigen detected in the blood during the incubation period of serum hepatitis. Proc. nat. Acad. Sণ (Wash.), 60, 814-821.

Roholm, K., and Iversen, P. (1939). Changes in the liver in acuie epidemic hepatitis (catarrhal jaundice), based on thirty-eigh aspiration biopsies. Acta path. microbiol. scand., 16, 427-44@ Schaffner, F., and Popper, H. (1969). Electron microscopy in live 
disease. In Diseases of the Liver, edited by Leon Schiff, 3rd ed. pp. 64-66. Lippincott, Philadelphia, Toronto.

Shaldon, S., and Sherlock, S. P. V.(1957). Virus hepatitis with features of prolonged bile retention. Brit. med. J., 2, 734-738.

Sherlock, S. P. V. (1946). Biochemical investigations in liver disease: some correlations with hepatic histology. J. Path. Bact., 58, 523-544.

Watson, C. J., and Hoffbauer, F. W. (1946). The problem of pro- longed hepatitis with particular reference to the cholangiolitic type and to the development of cholangiolitic cirrhosis of the Ann. intern. Med., 25, 195-227.

Weinbren, K. (1952). The pathology of hepatitis. J. Path. Bact., 64, liver. 395-413.

Weinfeld, A., Lundin, P., and Lundvall, O. (1968). Significance for the diagnosis of iron overload of histochemical and chemical iron in the liver of control subjects. J. clin. Path., 21, 35-40. 